Економічні науки: збірник наукових прачь Луиького національного технічного університету. Серія "Регіональна економіка". Випуск 17 (67). Редкол.: відп. ред. к.е.н., професор І.В. Кривов’язюк. Луцьк: ІВВ Луцького НТУ, 2020. 348 с.

УДК 338.2

Корольчук Л.В., к.е.н., доцент

Луцький національний технічний університет

\title{
АНАЛІЗ ДОСВІДУ ДЕРЖАВНОГО СТРАТЕГІЧНОГО ПЛАНУВАННЯ В УКРАЇНІ
}

\begin{abstract}
В статті проаналізовано досвід державного стратегічного планування в Україні; досліджено основні державні стратегічні документи України, виявлено об'єктивні причини низької ефективності реалізації стратегій; висунуто пропозиції щодо вирішення існуючих проблем у сфері державного стратегічного планування в Україні.
\end{abstract}

Ключові слова: державне стратегічне планування, державні стратегічні документи, національна стратегія, галузева стратегія.

\section{Korolchuk L.}

\section{ANALYSIS OF THE STATE STRATEGIC PLANNING EXPERIENCE IN UKRAINE}

One of the reasons for the low level of socio-economic development of Ukraine is the lack of a comprehensive approach to strategic planning. Today, the actions of the legislature and the executive are conditioned by either temporary economic or social challenges or the commercial interests of certain groups or individuals, and that is why they often do not correspond to the declared course of reforms and are more formal. The dominance of formality in approaches to strategic planning puts in the background in the development of strategies the principle of integrity, coherence between planning and strategic documents, the relationship between strategic goals and budget, as well as the principle of unity in approaches to assessing the effectiveness of strategies.

This state of affairs may have a negative impact not only on the quality of life of modern Ukrainians, but also on future generations, as the lack of quality structural changes and comprehensive reforms in the economy over time will lead to permanent and persistent chaos in the economic system and, consequently, prolonged depression. and resource depletion, etc. Careful study of the state strategic planning in our country will identify the main problems in this area, which, in turn, will allow to develop effective mechanisms for their timely solution in the future.

The article analyzes the experience of state strategic planning in Ukraine; the main state strategic documents of Ukraine are studied: Sustainable Development Strategy «Ukraine- 2020» and a number of existing sectoral strategies; the objective reasons of low efficiency of realization of strategies are revealed; proposals were 
Економічні науки: збірник наукових прачь Луиького національного технічного університету. Серія "Регіональна економіка". Випуск 17 (67). Редкол.: відп. ред. к.е.н., професор І.В. Кривов’язюк. Луцьк: ІВВ Луцького НТУ, 2020. 348 с.

made to solve the existing problems in the field of state strategic planning in Ukraine.

Key words: state strategic planning, state strategic documents, national strategy, branch strategy.

Корольчук Л.В.

\section{АНАЛИЗ ОПЫТА ГОСУДАРСТВЕННОГО СТРАТЕГИЧЕСКОГО ПЛАНИРОВАНИЯ В УКРАИНЕ}

В статье проанализирован опыт государственного стратегического планирования в Украине; исследованы основные государственные стратегические документы Украины, выявлены объективные причины низкой эффективности реализации стратегий; выдвинуты предложения по решению существующих проблем в сфере государственного стратегического планирования в Украине.

Ключевые слова: государственное стратегическое планирование, государственные стратегические документы, национальная стратегия, отраслевая стратегия.

Постановка проблеми у загальному вигляді та її зв'язок 3 важливими науковими та практичними завданнями. Однією 3 причин низького рівня соціальноекономічного розвитку України вважається відсутність комплексного підходу до стратегічного планування. Сьогодні дії законодавчої та виконавчої влади обумовлені або тимчасовими економічними чи соціальними викликами, або комерційними інтересами окремих груп чи осіб і саме тому часто не відповідають задекларованому курсу реформ, носять більшою мірою формальний характер. Саме домінування формальності у підходах до стратегічного планування відносить на задній план при розробці стратегій принцип цілісності, узгодженості між плановими та стратегічними документами, взаємопов'язаності між стратегічними цілями та бюджетом, а також принцип єдності у підходах до оцінки ефективності реалізації стратегій.

Такий стан речей може негативно відбитися не лише на якості життя сучасних українців, але й наступних поколінь, поскільки відсутність якісних структурних перетворень та комплексних реформ в економіці на протязі довгого часу 
Економічні науки: збірник наукових прачь Луиького національного технічного університету. Серія "Регіональна економіка". Випуск 17 (67). Редкол.: відп. ред. к.е.н., професор І.В. Кривов'язюк. Луиьк: ІВВ Луцького НТУ, 2020. 348 с.

призведе до перманентного та стійкого хаосу в економічній системі i, як наслідок, до затяжної депресії та ресурсного виснаження тощо. Ретельне дослідження стану стратегічного планування в нашій державі дозволить виявити основні проблеми у цій сфері, що, в свою чергу, дасть можливість розробити ефективні механізми їх своєчасного вирішення в подальшому.

Аналіз останніх досліджень, у яких започатковано вирішення проблеми. Вагомий внесок у розвиток теорії державного стратегічного планування, a саме у розробку методики побудови стратегій, обгрунтування ролі стратегій у державній політиці, визначення етапів стратегічного планування, розробку інструментарію практичної реалізації стратегій в умовах транзитивної економіки тощо, зробили такі вітчизняні вчені, як А.С. Гальчинський, Л.О. Мусіна, В. Горбулін, Н. Нижник, Ю. Шаров, Я. Жаліло, О. Трухан та ін. Такі зарубіжні вчені, як Дж. Гелбрейт, П. Друкер, У. Кінг, Д. Кліланд, Дж. Б. Куїнн, Дж. Стейнер, Д. Хассі та ін. мають оригінальні доробки у сфері стратегічного менеджменту, який і становить собою теоретичне підгрунтя для розвитку державного стратегічного планування.

Цілі статті: проаналізувати досвід державного стратегічного планування в Україні; дослідити основні державні стратегічні документи України, виявити об'єктивні причини низької ефективності реалізації стратегій; висунути пропозиції щодо вирішення існуючих проблем у сфері державного стратегічного планування в Україні.

Виклад основного матеріалу дослідження 3 повним обгрунтуванням отриманих наукових результатів. Перші спроби формування системи стратегічного планування в Україні були здійснені за часів президентства Леоніда Кучми, який видав два знакових для даної сфери Укази:

- Указ Президента № 314/97 «Про щорічні послання Президента України до Верховної Ради України» від 9 квітня 1997 р. , який був покликаний забезпечувати цілеспрямовану 
Економічні науки: збірник наукових прачь Луиького національного технічного університету. Серія "Регіональна економіка". Випуск 17 (67). Редкол.: відп. ред. к.е.н., професор І.В. Кривов'язюк. Луиьк: ІВВ Луцького НТУ, 2020. 348 с.

роботу всіх гілок влади в напрямі досягнення пріоритетів, визначених у посланні Президента[1];

- Указ Президента № 460/99 «Про впровадження системи стратегічного планування та прогнозування» від 30 квітня 1999 p., що забезпечив створення Центру інформаційних ресурсів та технологій, на який було покладено функції організації, інформаційного забезпечення та науково-аналітичного супроводу діяльності Ради національної безпеки і оборони України щодо впровадження системи стратегічного планування і прогнозування у сфері економічної та інформаційної безпеки, розроблення відповідних інформаційних ресурсів і технологій та підготовки кадрів[2].

Першою стратегією в історії незалежної України була Стратегія економічного та соціального розвитку України на 2004-2015 pр. «Шляхом європейської інтеграції» підготовлена у відповідності до розпоряджень Президента України №372/2001рп від 21.12.2001 р. та №385/2002-рп від 01.11.2002 р. Основні прогнозі макроекономічні показники розвитку України розглянуто на розширеному засіданні Кабінету Міністрів України та Президії Національної академії наук України 12 березня 2004 року. Над підготовкою тексту працювали фахівці під науковим керівництвом Радника Президента України директора Національного інституту стратегічних досліджень, доктора економічних наук, професора А.С. Гальчинського та директора Інституту економічного прогнозування НАН України, академіка НАН України В.М. Гейця. Базовими інституціями у підготовці Стратегії були Національний інститут стратегічних досліджень, Інститут економічного прогнозування НАН України та Міністерство економіки та 3 питань європейської інтеграції України. При підготовці Стратегії використовувалися аналітично-прогнозні матеріали міністерств і відомств України, Національного банку України, обласних державних адміністрацій, міжнародних організацій та фахівців [3].

Як бачимо, дана стратегія мала потужну науковоаналітичну базу, але, попри все, це не забезпечило досягнення задекларованих цілей на практиці, таких як: створення 
Економічні науки: збірник наукових прачь Луиького національного технічного університету. Серія "Регіональна економіка". Випуск 17 (67). Редкол.: відп. ред. к.е.н., професор І.В. Кривов'язюк. Луиьк: ІВВ Луцького НТУ, 2020. 348 с.

передумов для набуття Україною повноправного членства в СС; забезпечення сталого економічного зростання; утвердження інноваційної моделі розвитку; соціальна переорієнтація економічної політики [3]. Трагічні події, які розгорілися на майдані в кінці 2013 року в знак протесту молоді проти відмови діючого на той час президента України підписувати Угоду про асоціацію 3 ЄС $є$ беззаперечним підтвердженням низької ефективності реалізації національної стратегії в практичній площині.

Сьогодні діючою загальнонаціональною стратегією України, яка прийшла на зміну попередній є Стратегія сталого розвитку «Україна-2020» [4]. Крім того існує низка галузевих стратегій, які покликані розвивати пріоритетні сфери економіки країни в рамках реалізації загальнонаціональної стратегії. До таких відносяться: Стратегія національної безпеки України до 2020 року, Державна стратегія регіонального розвитку на період до 2020 року, Стратегія розвитку аграрного сектору економіки на період до 2020 року, Стратегія державної екологічної політики України на період до 2020 року, Енергетична стратегія України на період до 2030 року, Стратегія розвитку інформаційного суспільства в Україні (2013-2020), Стратегія сталого розвитку України на період до 2020 року, Транспортна стратегія України на період до 2020 року, Експортна стратегія України: Дорожна карта стратегічного розвитку торгівлі на період 2017-2021 років, Стратегія подолання бідності до 2020 року, Національна стратегія у сфері прав людини (до 2020 року), Стратегія розвитку високотехнологічних галузей до 2025 року, Національна стратегія розвитку освіти в Україні на період до 2021 року, Стратегія розвитку туризму та курортів на період до 2026 року, Довгострокова стратегія розвитку української культури стратегія реформ (з 2016 року), Стратегія реформування судоустрою, судочинства та суміжних правових інститутів на 2015-2020 роки, Національна стратегія державної політики сприяння розвитку громадянського суспільства в Україні на 2016-2020 роки та інші. 
Економічні науки: збірник наукових прачь Луиького національного технічного університету. Серія "Регіональна економіка". Випуск 17 (67). Редкол.: відп. ред. к.е.н., професор І.В. Кривов'язюк. Луиьк: ІВВ Луцького НТУ, 2020. 348 с.

Як бачимо термін реалізації більшості 3 перечислених стратегій доходить до кінця, тому можна аналізувати їх ефективність та результативність. Так, відповідно до аналізу державних стратегічних документів України щодо врахування адаптованих для України Цілей Сталого Розвитку до 2030 року, здійсненого Інститутом суспільно-економічних досліджень України цілі сталого розвитку, адаптовані до українських умов, включено у державну політику лише частково. Крім того, вирішення деяких завдань сталого розвитку взагалі не передбачено жодним державним стратегічним документом. В окремих стратегіях немає цільових індикаторів, термінів i графіків виконання (наприклад: № 11 Сталий розвиток міст громад; № 14 Збереження морських ресурсів). Результати аналізу, здійсненого експертним методом, демонструють, що загалом лише близько $60 \%$ завдань цілей сталого розвитку інкорпоровано в аналізовані стратегії [5].

Варто відзначити, що пункти окремих статей Угоди про асоціацію між Україною і Свропейським Союзом передбачають, що їх упровадження має сприяти реалізації цілей сталого розвитку в Україні. Водночас частина проаналізованих стратегій повністю оминають завдання цілей сталого розвитку навіть тоді, коли останні мало би бути представлено з огляду на сферу i предмет таких державних стратегічних документів [5].

Таким чином, до основних причин та обмежень, що заважають досягненню цілей сталого розвитку відносяться [5]:

1) Відсутність логічного взаємозв'язку між фрагментами циклу аналізу політики в Україні; 2) відсутність громадського контролю за ефективністю реалізації державної стратегії; 3) відсутність інституційного механізму інкорпорації цілей сталого розвитку у державну політику.

Висновки. На наш погляд, державне управління в Україні ще досі носить на собі відтінок радянського минулого, епохи планової економіки та бюрократизації, коли складання стратегічних планів та програм було самоціллю, їх виконання не контролювалось громадськістю і тому вони носили більшою мірою формальний характер. Такий стан речей вимагає 
Економічні науки: збірник наукових прачь Луиького національного технічного університету. Серія "Регіональна економіка". Випуск 17 (67). Редкол.: відп. ред. к.е.н., професор І.В. Кривов'язюк. Луиьк: ІВВ Луцького НТУ, 2020. 348 с.

посилення громадського контролю за виконанням завдань, прописаних в державних стратегічних документах, на місцях, а отже - створення більшої кількості неурядових організацій, які б займалися моніторингом роботи чиновницького апарата тощо. Сьогодні важливо відокремити державне стратегічне планування від амбіцій та прагнень діючої на той, чи інший момент влади, від політичних пріоритетів правлячих партій, інакше кажучи, державна стратегія - це довгостроковий план розвитку держави, реалізацію якого повинні забезпечувати усі діючі чиновники, незалежно від їх партійної приналежності та особистих інтересів. Доцільно, щоб забезпечення дотримання стратегічного курсу держави реальними діями (ефективно виконаними програмами) стало головним критерієм під час народних виборів до органів місцевої та центральної державної влади. Необхідне запровадження механізмів перманентної взаємодії влади та громадян, щоб голоси виборців на користь тої, чи іншої політичної сили нарешті перестали бути просто громадянським обов'язком та кредитом довіри українців, а почали становити собою реальну оцінку рівня забезпечення претендентами національних пріоритетів та інтересів України.

\section{Список бібліографічного опису}

1. Про щорічні послання Президента України до Верховної Ради України : Указ Президента України від 9 квіт. 1997 р. № 314/97. URL: https://zakon.rada.gov.ua/laws/show/314/97\#Text.

2. Про впровадження системи стратегічного планування та прогнозування: Указ Президента України від 30 квітня 1999 р. № 460/99. URL: https://zakon.rada.gov.ua/laws/show/460/99\#Text.

3. Стратегія економічного та соціального розвитку України на 20042015 pp. «Шляхом європейської інтеграції». URL: http://www.irbisnbuv.gov.ua/cgi-

in/ua/elib.exe?Z21ID=\&I21DBN=UKRLIB \&P21DBN=UKRLIB \&S21STN=1\&S21 $\underline{\mathrm{REF}}=10 \& \mathrm{~S} 21 \mathrm{FMT}=$ online $\_$book $\& \mathrm{C} 21 \mathrm{COM}=\mathrm{S} \& \mathrm{~S} 21 \mathrm{CNR}=20 \& \mathrm{~S} 21 \mathrm{P} 01=0 \& \mathrm{~S} 21 \mathrm{P} 02$ $=0 \& \mathrm{~S} 21 \mathrm{P} 03=\mathrm{FF}=\& \mathrm{~S} 21 \mathrm{STR}=\mathrm{ukr0001330}$.

4. Стратегія сталого розвитку «Україна-2020». URL: https://zakon.rada.gov.ua/laws/show/5/2015\#n10.

5. Аналіз державних стратегічних документів України щодо врахування адаптованих для України Цілей Сталого Розвитку до 2030 року: Резюме аналітичної доповіді. К.: Інститут суспільно-економічних досліджень, 
Економічні науки: збірник наукових прачь Луиького національного технічного університету. Серія "Регіональна економіка". Випуск 17 (67). Редкол.: відп. ред. к.е.н., професор І.В. Кривов’язюк. Луцьк: ІВВ Луцького НТУ, 2020. 348 с.

2017. 20 c. URL: http://iser.org.ua/uploads/files/ISED_ReportUKR_Web_Final.pdf.

\section{References}

1. Pro schorichni poslannja Prezydenta Ukrajiny do Verhovnoji Rady Ukrajiny: Ukaz Prezydenta Ukrajiny vid 9 kvitnja 1997 roku. № 314/97. Available at: https://zakon.rada.gov.ua/laws/show/314/97\#Text [in Ukrainian].

2. Pro vprovagennja systemy strategichnogo planuvannja ta prognozuvannja: Ukaz Prezydenta Ukrajiny vid 30 kvitnja 1999 roku. № 460/99. Available at: https://zakon.rada.gov.ua/laws/show/460/99\#Text[in Ukrainian].

3. Strategija ekonomichnogo ta socialnogo rozvytku Ukrajiny na 20042015 roky. "Shljahom europejskoji integracii". Available at: http://www.irbisnbuv.gov.ua/cgi-

in/ua/elib.exe?Z21ID=\&I21DBN=UKRLIB\&P21DBN=UKRLIB\&S21STN=1\&S21 $\mathrm{REF}=10 \& \mathrm{~S} 21 \mathrm{FMT}=$ online book $\& \mathrm{C} 21 \mathrm{COM}=\mathrm{S} \& \mathrm{~S} 21 \mathrm{CNR}=20 \& \mathrm{~S} 21 \mathrm{P} 01=0 \& \mathrm{~S} 21 \mathrm{P} 02$ $=0 \& \mathrm{~S} 21 \mathrm{P} 03=\mathrm{FF}=\& \mathrm{~S} 21 \mathrm{STR}=\mathrm{ukr} 0001330$. [in Ukrainian].

4. Strategija stalogo rozvytku "Ukrajina-2020". Available at: https://zakon.rada.gov.ua/laws/show/5/2015\#n10. [in Ukrainian].

5. Analiz dergavnyh strategichnyh dokumentiv Ukrajiny schodo vrahuvannja adaptovanyh dlja Ukrajiny Cilej Stalogo Rozvytku do 2030 roku: resjume analitychnoji dopovidi. K.: Instytut suspilno-ekonomichnyh doslidgen. 2017. 20 p. Available at: http://iser.org.ua/uploads/files/ISED_ReportUKR_Web_Final.pdf [in Ukrainian]. 